\title{
Effectiveness of Marriage Services Through Information System Management (SIMKAH) at Palu City Religious Court
}

\author{
Imam Muslih ${ }^{1}$, Nurdin Nurdin ${ }^{2}$, Marzuki Marzuki ${ }^{3}$ \\ 1 Islamic Law Department, Postgraduate, Institut Agama Islam Negeri Palu \\ 2 Islamic Education Department, Postgraduate, Institut Agama Islam Negeri Palu \\ ${ }^{3}$ Islamic Law Department, Postgraduate, Institut Agama Islam Negeri Palu
}

\section{ABSTRACT}

This paper discusses the effectiveness of marriage services through Marriage Management Information System (SIMKAH) at Palu city religious court. This study used qualitative research method. The data was collected through indepth interview, observation, and document studies. The data was analyzed using grounded theory approach which begins with data reduction, presentation, analysis, and three level coding. The results show that the Marriage Management Information System (SIMKAH) has various purposes and functions. The marriage information system is used to anticipate data manipulation, and to facilitate a spouse in order to better understand how to register. The information system has been effectively used to serve couple who wants to marry. The system also reduce costs of marriage because it reduces time and registration cost.

\section{ARTICLE \\ INFORMATION}

Keywords:

Marriage services, information systems, SIMKAH, efectiveness 


\section{Introduction}

A good information system can convey, proceed and present accurate, fast, and precise data to and complete information. The use of information technology through information systems will not only improve services at the Religious Affairs Office and but also helps the office to generate information faster as well as to improve its management. With appropriate information technology, it would enable the office to create a better information management system which in turn would increase the integration of information and operations amongst various parties in an organization locally and globally.

The use of computers as an information technology tool is very much needed in almost every aspect of life. Today, the use of computers is widespread not only in work setting but also in everyday life. In this case, the use of computer is an absolute tool used in processing information and data and it fully supports stakeholders in decision making process.

Marriage Management Information System (SIMKAH) has become a major agenda of the Islamic Community Guidance. It supports Religious Affairs office to provide reliable marriage administration services. The SIMKAH which was built on an offline and online basis is now used as an effective way to overcome various shortcomings and weaknesses of the Office. For the office of Religious Affairs that has not yet provided internet network, the SIMKAH can be used for direct services and it would become a very effective data storage. Meanwhile, offices that already have internet network, they can directly go online and send their data to the Centre of Islamic Bimas server. ${ }^{1}$

The Marriage Management Information System (SIMKAH) which presents statistical data on marital events throughout Indonesia can also verify data of bride and groom. Moreover, the operation of the Marriage Management Information System (SIMKAH) application can integrate all administrative records from registration to publication of computerized marriage books, thereby hoping to increase public understanding about marriage registration. To create effective, accurate and accountable services, the office of religious affairs must be supported by adequate electronic devices and reliable human resources.

The Office of Religious Affairs (KUA), East Palu District, Palu is part of the local government agency tasked with providing services to local community. It functions as a spearhead of the implementation of general government tasks, especially in the field of religious affairs. The Office of Religious Affairs (KUA), East Palu District, Palu, has made several efforts at its best potential, capabilities and facilities to provide best services.

The Office of Religious Affairs (KUA) of East Palu District, Palu, is the spearhead of the Ministry of Religious

1 Rusli, R. (2017). Wahdah Islamiyyah Palu: on Contemporary Islamic Legal Issues in The Internet. Hunafa: Jurnal Studia Islamika, 14(2). 
Affairs (MoRA) which carries out governmental tasks in the field of Islamic Religious affairs in the District. The position of the Office of Religious Affairs (KUA) of East Palu District, Palu is central because it directly serves community nearby.

In addition, the office is demanded to be fully capable of carrying out various religious and social tasks including marriage services implementing the Marriage Management Information System (SIMKAH). This service is the main task of the office.

Having organized and effective marriage services, the office would support the establishment of a peaceful, caring and loving (sakinah, mawadah and warahmah) family. ${ }^{2}$ In carrying out duties in these affairs the office not only records marriage / reconciliation, but it also carries out other tasks such as managing and fostering places of worship for Muslims (mosques and / mushallas), giving alms/charities (zakat), endowments, charity houses (Baitul Mal) and social worship, lawful and unlawful (halal) food, peaceful and caring, loving family development, and other non-civil servant religious counseling.

Like other agencies, the local Office of Religious Affairs functions as a service provider where it has to provide satisfactory services to its community. The Office which is structurally under the sponsorships of Islamic Community

${ }^{2}$ Rusli, R. (2017). Wahdah Islamiyyah Palu: on Contemporary Islamic Legal Issues in The Internet. Hunafa: Jurnal Studia Islamika, 14(2).
Guidance (BIMAS ISLAM) oversees several service units such as marriage, reconciliation, and other religious services.

The Office is a government agency in the district of East Palu promotes the Marriage Management Information System (SIMKAH) program as an excellent IT-based public service. ${ }^{3}$

The implementation of Marriage Management Information System (SIMKAH) was established in December 2014. It is in line with the enactment of the Government Regulation no 48 regarding cost of marriage. This Marriage Management Information System (SIMKAH) has been implemented in other regions and the results show good progress which could be taken into account in the Office of Religious Affairs (KUA) of East Palu District.

The implementation of Marriage Management Information System (SIMKAH) at the Office of Religious Affairs (KUA) of East Palu District is aimed to develop better, effective and efficient services in accordance with the Office Motto is "KALEDO" namely Creative, Trustful, Flexible, Empathy, Dedicative and Objective.

This is an interesting point to consider for the study. The effectiveness of services using the Marriage Management Information System

3 Nurdin. (2014, 28-30 May 2014). Understanding government e-procurement effectiveness from users' perspectives: A case of social media discussion in Indonesia local government. Information and Communication Technology (ICoICT), 2014 
(SIMKAH) allows for effective and efficient services to take place. Therefore, it could easily serve community especially in regards to marital problems. In addition, the implementation of the Marriage Management Information System (SIMKAH) could help the office to inspect and supervise marriages faster than before and help community to better understand duties and responsibilities of the office. As a result, it is not surprising, there is an impression that duties and functions of the Office of Religious Affairs (KUA) are only limited to prayer and marriage.

Preliminary data were obtained in the field through the implementation of the Marriage Management Information System (SIMKAH) at the Office of Religious Affairs (KUA) of East Palu District. During the preliminary data collection, the Office of Religious Affairs (KUA) officers can easily supervise, and examine every file of two brides who want to get married. Hence, there is no data manipulation in this context.

\section{Literature review}

2.1 Marriage Management Information System (SIMKAH)

In most cases, marriage regulations have been rejected by the majority of the Muslim. The regulation was rejected because it gave Muslims the opportunity to marry at the Civil Registry Office, impose a monogamous principle, and determine that divorce only falls if it is done through a court decision. This should be noted in 1937 in Solo, an organization of assemblers and employees was established. The leader in the Dutch East Indies colonial era and at the beginning of independence was only known in Java and Madura. ${ }^{4}$

One of the milestones in that period, one year after the MoRA was founded on January 3, 1946 with the first Minister H.M. Rasjidi, is the birth of the Law No.22, 1946 concerning registration of marriage, divorce and reconciliation. ${ }^{5}$

According to the Marriage Registration Law, Divorce and Referral, marriages carried out according to the Islamic Religion, are supervised by marriage registration employees who were appointed by the Minister of Religious Affairs or employees who were appointed by the authorities. Divorce and reconciliation carried out according to Islamic teaching, were notified to the marriage registrar. Those who are entitled to supervise marriages and receive notifications about divorce and reconciliation are only employees appointed by the Minister.

In the past, the Office of Religious Affairs (KUA) had a vertical structure to the provincial level and was under the position of Religious Affairs of the Ministry of Religious Affairs (MoRA) in the Greater Jakarta Municipality (now DKI Jakarta), and the formation of religious offices was carried out in 1950 initiated by HSM Nasaruddin Latif, $\mathrm{H}$. Sulaiman Rasjid and HZ Arifin Datuk, which covers Religious Affairs, Religious education and Religious information. ${ }^{6}$

\footnotetext{
${ }^{4}$ Ibid., 16

5 Ibid., 17

${ }^{6}$ Ibid., 18
} 
The regulation of Minister of Religious Affairs No. 9, 1952 and the Government Regulation No. 8, 1950 made mention that the duties of the Ministry of Religious Affairs in matters of marriage are: to organize, work and observe all matters related to registration of marriage, divorce and referrals who are Muslim. Meanwhile, matters of marriage outside Islam are not regulated by the Ministry of Religious Affairs.7

\section{Marriage service}

In Indonesian dictionary, the word 'service' is to help, to take care or prepare all the needs needed by someone or serving people. ${ }^{8}$

Hardiyansah defines that "service can be interpreted as an activity given to help, prepare, and take care of either in the form of goods or services from one party to another".Service is essentially a series of activities, therefore service process takes place routinely and continuously, covering the entire life of the organization in society. The intended process is carried out in connection with meeting the needs of recipients and service providers. ${ }^{9}$

In essence, the government operates two main types of functions, namely regulatory function and service function. Regulatory function is usually

${ }^{7}$ Ibid., 18

8 Team Reality, Kamus Terbaru Bahasa Indonesia dilengkapi: EYD;Ejaan yang Disempurnakan, (Cet. I, Relaity Publisher: Surabaya, 2008), 412.

9 Hariyansyah, Kualitas Pelayanan Publik, Konsep, Dimensi, Indikator, dan Implementasinya. (Yogyakarta: Gava Media, 2011), 11. associated with nature of a modern state as a legal state, while service function is related to nature of a state as a welfare state.

There are three public service functions performed by government, namely environmental service, development service and protective service. ${ }^{10}$ Services by government also differ based on who enjoys or receives impact of services, both individuals and groups. The concept of service goods basically consists of private goods and public goods. ${ }^{11}$

Service is the main activity for people engaged in services, both commercial and non-commercial. However, in practice there is a difference between services performed by commercial people who are usually managed by private parties and services carried out by non-commercial organizations (government). Commercial services carry out activities for profit, while noncommercial services are more focused on providing services to public for nonprofit orientation.

As a public service institution, the improvement of service process in the field of marriage is directed to produce an accountable and transparent service

10 Nurdin, N. (2016) The Roles of Information Technology In Islamic Bank Knowledge Management: A Study of Two Syariah Banks in Palu. Hunafa: Jurnal Studia Islamika, 13(2), 181-217. https://doi.org./https://doi.org/10.24239/jsi.v 1

11 M.Ervan Marzuki dan Hasbi Mustofa, Efektifitas Pelayanan di Seksi Bimbingan Masyarakat Islam Kantor Kementerian Agama, (tth).6.

e-ISSN: 2715-4580 p-ISSN: 2715-8268 
process, and has a fast and concise performance. It could describe each type of work output comprehensively, conduct analysis and evaluation to obtain a detailed picture of tasks performed by each agent. Moreover, it is to conduct workload analysis to be able to obtain information about time and number of workers needed to carry out that service.

In an effort to improve quality of services in marriage, Standard Operating Procedures (SOP) are needed to improve services to the community. Optimal public services are believed to increase public trust in the government. Standard Operating Procedure (SOP) is a written stipulation of what to do, when, where and by whom. ${ }^{12}$ SOPs are made to avoid variations in the process of implementing activities that will interfere the overall organizational performance. SOP is a mechanism driving organizations / institutions to be able to function effectively and efficiently.

\subsection{Marriage service procedures}

The procedures for carrying out marriage services are elaborated in the following order:

\section{Notification}

The Article 5 of Law No. 1, 1974 states that procedure for notification of a marriage plan can be done verbally or in writing by bride and groom's parents or

12 Iqbal, M., Rusli, R., dan Musyahidah, M. (2019). Management Strategies of Professional Zakat Funds for Mustahiq Family Welfare by Amil Zakat Body. International Journal Of Contemporary Islamic Law and Society, 1(1), 35-51. representatives. The notice is determined no later than 10 days before the marriage takes place. As for the information notified covers name, age, religion, occupation, address, and if one or both of them have been married previously, then the name of his wife or her husband should also be mentioned.

\section{Research}

In the case of marriage, the Marriage Registrar must examine the origins of bride and groom including their respective marital status. Marriage registry employees are also required to be informed in relation to birth certificate of bride and groom. In this context, when there is no birth certificate to be used for recognizing ages and origin of bride and groom, a letter of statement from the head of village where they live or the equivalent is needed. ${ }^{13}$

Based on the above information, it can be explained that two brides who wish to carry out their marriages must fulfill procedures as described. The aim is to provide accurate and valid data or information to the marriage registrar. Hence, the results of the Registrar are then written in a marriage register which is called the Marriage Management Information System (SIMKAH). However, if the results of the observation of the registrar indicate invalid data and information about bride and groom which means potential obstacles for their marriage, the employee notifies the prospective bride or parents or representatives.

13 Suyuthi Thalib, Hukum Kekeluargaan Indonesia (Jakarta:UI Press, 1986), h. 47-48

e-ISSN: $2715-4580$ p-ISSN: 2715-8268 


\section{Announcement}

When the problem has been resolved, the Registrar records an announcement about the intention to hold a marriage by an announcement letter based on the form determined at the Marriage Registration Office and must be signed by the Marriage Registrar. If the conditions have been met as stated above, the marriage can be carried out as it should. The purpose of the announcement is to publicize the bride and groom to marry. In addition, with the announcement, if there are parties who object to the marriage, the person concerned can submit an objection to the marriage registration office. With the service procedure for marriage, it will be easier for the Office of Religious Affairs (KUA) to track and search for the bride's identity if there is a fraud or a peculiarity in the marriage later on.

\subsection{Marriage Management Information System (SIMKAH)}

It is commonly known that the Office of Religious Affairs (KUA) is the spearhead of the Ministry of Religious Affairs (MoRA). It is not wrong, because it is so. Many social and religious matters are responsibility of the Office of Religious Affairs (KUA), such as taking care of marriage of reconciliation, endowments, Hajj guidance, Islamic religious counseling, to religious data and information centers at the subdistrict level. Therefore, it is not surprising, the Office of Religious Affairs (KUA) becomes a mirror of the MoRA, especially in marriage services.

Prior to the use of the Marriage Management Information System
(SIMKAH), the registration procedure at the Office of Religious Affairs (KUA) proceeded to follow the rules contained in the government Regulation No. 9 1975 concerning the implementation of Law Number 11974 in regards to Marriage. The rule is then followed up by the rules of MoRA number 11, 2007 regarding marriage registration and Decree of the General Director of Islamic Community Guidance Number DJ.II / 1142, 2013 concerning Technical Instructions for filling and issuing Marriage Certificate. ${ }^{14}$

Marriage registration can be done by writing and typing it when computers are available. However, before the regulation of the General Director of Islamic Community Guidance Number DJ.II / 369, 2013 concerning the Application of Marriage Management Information System (SIMKAH) at the Office of Religious Affairs (KUA), the method of writing in the process of registration, marriage examination, and registration of marriage events, divorce / divorce and referral is written in block letters and uses black ink. ${ }^{15}$

Marriage registration carried out by an appointed employee is one of the most important processes. This is due to legal consequences, which are legal and recognized by the State. In each region, especially in the Village, marriage registration process according to the Regulation of MoRA No. 11, 2007 can be

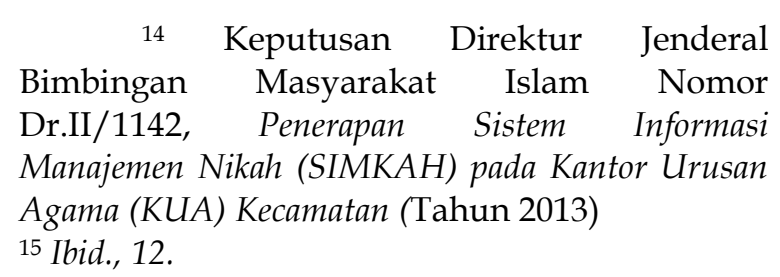

e-ISSN: $2715-4580$ p-ISSN: 2715-8268 
assisted by the Marriage Registrar Assistant.

However, in line with the existence of a Marriage Management Information System (SIMKAH), marriage registration is carried out by a leading figure. The marriage registration through the Marriage Management Information System (SIMKAH) is carried out by an operator. The use of a Marriage Management Information System (SIMKAH) makes the work of the Office of Religious Affairs (KUA) faster and more efficient. In some case, however, the Office of Religious Affairs (KUA) which do not yet have adequate employees and computerized facilities using the Marriage Management Information System (SIMKAH), the marriage management becomes less effective.

Internally, the MoRA has a strong commitment to change the image of the Office of Religious Affairs (KUA) as a clean and serving institution. Regional policy makers have officially stated that they want to make the Office of Religious Affairs (KUA) as a public institution that carries out their duties professionally, transparently and accountably. This effort has also been supported by the macro policies of the General Directorate of Islamic Community Guidance to improve administrative services through the Marriage Management Information System (SIMKAH) under the umbrella of the Islamic Guidance Management Information System (SIMBI).

The Marriage Management Information System (SIMKAH) was initiated with the idea that services today should be online-based ones. There are four benefits found in the Marriage Management Information System (SIMKAH), namely:

1. This application presents statistics on marital events throughout Indonesia for the Office of Religious Affairs (KUA)

2. This application can verify data for areas that have worked with the District Office for Demography and Civil Affairs.

3. The announcements of marriage plans can be widely publicized

4. Online marriage registration can be implemented immediately. ${ }^{16}$

With the Marriage Management Information System (SIMKAH), it has now become a national epidemic and has received serious attention from the General Directorate of Islamic Community Guidance. The use of the Marriage Management Information System (SIMKAH) has also become one of the elements of evaluation in the selection of the National Exemplary Religious Affairs Office (KUA) in 2013. Moreover, in 2015 the development of the Islamic Community Guidance Management Information System (SIMBI) in which there is a Marriage Management Information System (SIMKAH) was made as the Government Program Plan (RKP) which had to be carried out by the Bimas Islam.

\section{Methodology}

$16 \quad$ Bimbingan
$\begin{aligned} & \text { Masyarakat } \\ & \text { Kementerian Aslam } \\ & \text { Baru KUA, } 12 .\end{aligned}$
e-ISSN: $2715-4580$
p-ISSN: $2715-8268$


This study uses a qualitative approach with the object of research is the Office of Religious Affairs (KUA), East Palu District, Palu. The rationale is that the researchers observed that the Office of Religious Affairs (KUA) has long implemented the Marriage Management Information System (SIMKAH) program. In addition, the researchers want to investigate how the Marriage Management Information System (SIMKAH) program could make marriage affairs far easier than before including how to track identity or status of bride and groom to be. They were interested to better understand whether the operator of the Marriage Management Information System (SIMKAH) program could operate the program with or without coaching.

Data were collected through observation techniques, in-depth interviews with the head of the Office of Religious Affairs (KUA), the headman, and the operator of the Marriage Management Information System (SIMKAH). Meanwhile, data analysis applies reduction and verification techniques with various data sources. ${ }^{17}{ }^{18}$ The reduced data is then analyzed by claiming to theoretical concepts used in this study. ${ }^{19}$

17 Nurdin, N. (2017a). Research in Online Space: The Use of Social Media for Research Setting Jurnal Sistem Informasi (Journal of Information System), 13(1), 67-77.

18 Nurdin, N. (2017b). To Research Online or Not to Research Online: Using Internet-Based Research in Islamic Studies Context. Indonesian Journal of Islam and Muslim Societies, 7(1), 31-54.

19 Nurdin, N. (2016). The Roles of Information Technology in Islamic Bank Knowledge

\section{Result and Discussion}

4.1 Effectiveness of Marriage Management Information System Services (SIMKAH)

The effectiveness of a program is seen from various aspects, including in terms of Standard Operating Procedures (SOP) as a reference for the implementation of the Marriage Management Information System program. This procedure must also be planned with qualified Human Resources (HR) as an effort to optimize the implementation of the program. In addition, it is equally important to look over competitors as an effort for a sustainable improvement.

The effectiveness of the Marriage Management Information System (SIMKAH) program can also be seen from another angle. It is important to observe whether the SIMKAH program is in accordance with the vision of the KUA. On top of that, it is equally imperative to observe the mission of the Marriage Management Information System (SIMKAH) program. Hence, the researcher would better explain the condition of the Marriage Management Information System (SIMKAH) program at the Office of Religious Affairs (KUA) in the East Palu District whether the SOP determined by the MoRA has been fully implemented. The following are indicators of the effectiveness of the

Management: A study of Two Syariah Banks in Palu. Hunafa: Jurnal Studia Islamika, 13(2), 181217. https://doi.org/https://doi.org/10.24239/jsi.v 13i2.444.181-217 
Marriage Management Information System (SIMKAH) in KUA of East Palu: Based on the comparison between SOPs and the conditions of the Marriage Management Information System (SIMKAH) Office of Religious Affairs (KUA), East Palu District, it can be concluded that the Marriage Management Information System (SIMKAH) program has been so far effective because it has meet the SOP set by the MoRA. The utilization of the Marriage Management Information System (SIMKAH) has reached its ideal achievement.

As a restoration center, the Office of Religious Affairs (KUA) of East Palu District of Palu must own and improve the City in relation to the improvement of next generation. Hence, when the Marriage Management Information System (SIMKAH) operator is absent, other employees who have been entrusted by the Marriage Management Information System (SIMKAH) operator can operate the Marriage Management Information System (SIMKAH) program effectively.

The services carried out by the KUA of East Palu Sub-district concerning the Effectiveness of the Marriage Management Information System Services (SIMKAH) aim to increase effectiveness of services and management. The services provided and data must be accurate, timely to be provided to those who request it, and sent to the Regional Office of the Ministry of Religious Office of Central Sulawesi. As the researchers interviewed that:
"With the implementation of the Marriage Management Information System (SIMKAH) which is useful for collecting marriage data from all the Office of Religious Affairs (KUA) District so that the data can be safely protected. These data are useful for making various analyses and reports with various needs, at least there are 2 main objectives to be achieved namely; for uniformity and backup data. ${ }^{20}$

Uniformity of data is needed because it is expected that the data can be more effective and efficient so that it is easier to handle. Data backup is needed as an effort to save and collect data from various problems encountered such as natural disasters. With the SIMKAH, it is hoped that the data in the Sub-District Religious Affairs Offices throughout Indonesia can be uniform so that they can be quickly, accurately and efficiently analyzed.

The Marriage Management Information System (SIMKAH) program is designed to be used easily for its users. With the Marriage Management Information System (SIMKAH), although in its history of the establishment, many obstacles potentially become handicaps of its implementation. Now the SIMKAH has been endemic throughout Indonesia and received attention in particular by the General Directorate of Islamic Community Guidance. The use of the Marriage Management Information System (SIMKAH) has been an element for evaluating model of the Office of Religious Affairs (KUA). With

${ }^{20}$ Rasada, Kepala Kantor Urusan Agama KUA, Wawancara pada tanggal 23 Juli 2016. 
the Marriage Management Information System (SIMKAH), it becomes an application that is able to encourage good and clean governance. With this Marriage Management Information System (SIMKAH), efficient human resources, budget and time could be truly realized. The application of the Marriage Management Information System (SIMKAH) at the District Office of Religious Affairs (KUA) is one of the means to build the MoRA's image in terms of public services. The strategic value of the Office of Religious Affairs (KUA) as the leading unit of the MoRA at the District level will lead to a whole view of MoRA in regards to community service. Strengthening governance of the Marriage Management Information System (SIMKAH) at the Office of Religious Affairs (KUA) can be started by making strict and relevant regulations, so that it can be used as a legal umbrella, for stakeholders in the field. However, the availability of representative infrastructure and budget would be no less of importance.

The services carried out by the Office of Religious Affairs (KUA) in East Palu basically have fulfilled standard procedures. In order to create excellent service, documents and information received must be implemented and fulfilled in creating excellent service in accordance with the Vision and Mission of the Office of Religious Affairs (KUA), East Palu. The services performed must be in accordance with the request, in order to create the community and elevate the ranks of the Office of Religious Affairs (KUA), East Palu.
The results of the researchers' interviews with staff show that they have done services as ruled in the SIMKAH as they should. Service delivery in the Office of Religious Affairs (KUA) of East Palu District, as executors (staff) have followed the rules but consumes time to be able to work as expected by the agency. This is partly due to human resources in the KUA Office come from various disciplines.

The need for information technology for improving public services cannot be avoided. The development of powerful information technology must also be addressed with an open mind.

As a result, the Marriage Management Information System (SIMKAH) becomes a reliable application which could encourage the creation of good and clean governance. The successful management of a Marriage Management Information System (SIMKAH) would become a parameter in the administration of public services especially in the Islamic Community Guidance and the MoRA. To implement the program effectively, data diversification system is needed and integrated with data backup is needed. The Marriage Management Information System (SIMKAH) Program is designed to be used easily for all classes, both beginners and experts. The Marriage Management Information System (SIMKAH) Program at the Religious Affairs Office of the Office of Religious Affairs (KUA), East Palu District has implemented it online which makes it easy to verify data of prospective brides. This means that it would make it easier 
for any employee of the Office of Religious Affairs (KUA), East Palu for administering marriages.

Before the Marriage Management Information System (SIMKAH) was held, the Office of Religious Affairs (KUA) of East Palu in the City of Palu in examining files of bride and groom needed several employees to examine it. With the Marriage Management Information System (SIMKAH) program, it can be done by only 1 employee. As the author's interview elaborated as follows:

Alhamdulillah, with the Marriage Management Information System (SIMKAH) program, it can facilitate the entire examination of bride and groom which in the past (before the SIMKAH) were looked after by about 2-3 people because it was manually checked. Now, one employee is enough to handle the job of two or three staff before. ${ }^{21}$

The designated Married Management Information System (SIMKAH) operator staff can start entering data in marriage register folders, after the marriage registration process is carried out. From this marriage register entry, officers can be facilitated in the process of marriage registration in the form of module. Online related parties can monitor registration transactions within a week / month / year which are carried out in each Office of the Religious Affairs (KUA) more specifically the Office Religious Affairs (KUA) East Palu. From this marriage register data, it will be

21 Masyita, Operator SIMKAH, Wawancara pada tanggal 8 Juni 2017. able to print out reports of prospective brides who will get married within a week / month / year.

One of the duties of a headstaff is to process and verify data of bride and groom. Processing and verifying here means to examine the truth of each data of bride and groom, marriage guardian and witness at the Marriage Hall. Therefore, a headstaff is obliged to use his intelligence in the examination process. To avoid data manipulation, the Office of Religious Affairs (KUA) of East Palu cooperates with the KPU (General Election Commission) in verifying the population of East Palu residents. With this continuity, the data of Sub-district residents who want to get married in the Office of Religious Affairs Office of East Palu District will be identified.

The process of cooperation with the KPU is only temporary, that is, once in every 5 years or every presidential election of the Republic of Indonesia (RI). With this temporary nature, the data verification is also less valid, because the Office of Religious Affairs (KUA) does not know how the increase rate of citizens during these 5 years. From this KPU data, the office can find out number of residents of the East Palu Sub-district who can take part in the general election. The statement implies that if a person can vote for general election, he or she is considered valid for marriage.

With the Marriage Management Information System (SIMKAH) program, the Office of Religious Affairs (KUA) of East Palu hopes that it will 
ease marriage. It is also hoped that there will be no more manipulation of data from what is usually done to hold a second marriage. Hence, the institution of marriage as the gate to start national development can be well preserved. As the interview with the head of the Office of Religious Affairs (KUA), East Palu in the following way:

With this Marriage Management Information system can facilitate the community in providing information about the status of prospective spouses to each other. In addition, it can make it easier for employees of the Office of Religious Affairs (KUA) District of East Palu to track status of bride and groom's family. 22

Based on the explanation from the head of the Office of Religious Affairs (KUA), East Palu Sub-district, the Marriage Management Information System (SIMKAH) program has many advantages in comparison to manual marriage registration system. In line with the opinion of the head of the East Palu Religious Affairs Office, Masyita said that benefits felt in the use of the Marriage Management Information System (SIMKAH) program at the Office of Religious Affairs (KUA), East Palu are shown in following ways:

1. Easily adding, editing and deleting marriage data

2. Sending data reports easily online to the MoRA in regional offices and the Islamic Guidance

3. The program can check bride's identity through the KPU data so as to

\footnotetext{
${ }^{22}$ Rasada, Kepala Kantor Urusan Agama KUA, Wawancara pada tanggal 12 Juni 2017.
}

reduce errors and falsification of bride's identity

4. Backing up compressed data, so that large data can be stored in smaller storage media.

5. Data reporting can be easily published

6. It can speed up the disbursement of data for residents who have lost their marriage book

7. The data is kept neat and would avoid data loss. ${ }^{23}$

\subsection{Effectiveness of Marriage} Management Information Systems (SIMKAH)

With the Marriage Management Information System (SIMKAH) program at the Office of Religious Affairs (KUA) in East Palu District, bride and groom who wants to get married will be registered online, so they cannot get married twice by manipulating their marital status. The government will also obtain accurate data on marriage rates in Indonesia, especially in the city of Palu.

In the process of using the Marriage Management Information System (SIMKAH), it is necessary to enter the identity data of the applicants who want to get married, such as their full name, address, status, and identity of government employees or what is often referred to as N1 through N7 models. This function is to find out the authenticity of the identity of an applicant so that fabricated identity would not occur in the future.

23 Masyita, Operator SIMKAH, Wawancara pada tanggal 15 Juni 2017.

e-ISSN: $2715-4580$ p-ISSN: 2715-8268 
The services performed by the KUA of East Palu concerning the Effectiveness of Marriage Management Information System Services (SIMKAH) aim to improve effectiveness in services and management as well as sending data which is accurate, professional and accountable. The services provided and data must be accurate, timely provided to those who request it, and sent to the Regional Office of the Ministry of Religious Affairs of Central Sulawesi.

\section{Conclusions}

Services at the Office of Religious Affairs (KUA) of East Palu District of Palu were built on an offline and online basis in its attempt to overcome various weaknesses experienced at the East Palu Office of Religious Affairs (KUA). Services at the Office of Religious Affairs (KUA) were shown to be effective and efficient because it could create services by presenting "KALEDO" i.e. (Creative, Trustful, Flexible, Empathy, Dedicative, and Objective). This is the motto of the Office of Religious Affairs (KUA) East Palu . With the SMIKAH, data manipulation could be reduced by adjusting existing data in the Ministry of Demography and Civil Affairs (DUKCAPIL). Moreover, it has been used to facilitate bride and groom concerning mariage registration. It could make flow of wedding services effectively executed. The aim is to make it easier and easily understood by bride and groom if they want to register their marriage.
Arikunto, Suharsini, Prosedur Penelitian; Suatu Pendekatan Praktik. Jakarta: Rineka Cipta, 2010.

Abdul Aziz, bin, Shaleh, Nikah dengan Niat Talak?. Cet. I; Surabaya: Pustaka Progresif, 2004.

Aulia Nuansa, Kompilasi Hukum Islam; Hukum Perkawinan, Hukum Kewarisan, Hukum Perwakafan. Bandung: Nuansa Aulia, 2008.

Al-Asyhar, Thobib. SIMKAH, Cara Baru Pelayanan Administrasi Nikah di Era Digital. Kasubag Data dan Sistem Informasi Ditjen Bimas Islam: Konseptor Pidato Menag RI, 2014.

Abdul Aziz, Dahlan, Ensiklopedi Hukum Islam. Cet. Ke 4; Jakarta: PT Ikrar Mandiri Abadi, 2000.

Arifin, Muhammad Safitrah, http:// blogspot.com/2012/ektifitas Pelayanan Publik.html. Diakses pada tanggal 1 April 2017

As'at, Demiar. Penghulu Melek IT. Jurnal Pengulu, 4 Januari 2015.

Akbar, Ali, "Pelaksanaan Pelayanan Pernikahan Di Kua Kota Bengkulu". Tesis. (Bengkulu: master Thesis.Universitas Bengkulu, 2015).

B Davis, Gardon, Kerangka Dasar Sistem Informasi Manajemen. Jakarta: PT Pustaka Binaman Pressendo, 2002.

Bungin, Burhan, Metodologi Penelitian Kualitatif. Jakarta: Rajawali, 2010.

B. Milles, Matthew. et.al, Qualitative Data Analisys, diterjemahkan oleh Tjetjep Rohendi Rohidi dengan judul Analisis data Kualitatif, buku sumber tentang Metode-metode Baru. Cet. I; Jakarta: UI-Pres, 1992.

\section{References}


Bimbingan Masyarakat Islam Kementrian Agama RI, Bimas Islam, Paradigma Baru KUA.

C. Laudon, Kenneth, Sistem Informasi Manajemen. Jakarta: Salemba Empat, 2007.

Depertemen Agama RI, Alquran dan Terjemahannya. Ed. 2002; Jatinegara- Jakarta: CV Darus Sunnah, 2007.

Direktorat jenderal Bimbingan Masyarakat Islam Kementrian Agama RI, Bimas Islam, paradigma Baru KUA. Jakarta: Ed.no.I/Tahun 2014

Faisal, Sunafiah, Metode Penelitian Pendidikan. Surabaya:usaha Nasional, 1998.

Ghazaly, Abd. Rahman, Fiqih Munakahat. Jakarta: Kencana, 2006.

Handoko, T. Hani, Manajemen Edisi 2. Cet. ke 18, Yogyakarta: BPFEYogyakarta, 2003.

Hadi, Sutrisno, Metodologi Research Jilid I. Cet. XXIX; Yogyakarta: Andi Yogyakarta, 1997.

Hadikusuma, Hilman, Hukum Perkawinan Di Indonesia. Bandung: Mandar Maju, 1990.

Hamidi, Metode Penelitian Kualitatif. Malang : UMM Press, 2005.

Iqbal, M., Rusli, R., \& Musyahidah, M. (2019). Management Strategies of Professional Zakat Funds for Mustahiq Family Welfare By Amil Zakat Body. INTERNATIONAL JOURNAL OF CONTEMPORARY ISLAMIC LAW AND SOCIETY, 1(1), 39-51.

Irawan, Dodi, Sistem Manajemen Data Da Informasi Pendidikan Di Lingkungan Direktorat Jendral Kelembagaan
Agama Islam. Jakarta: Depertemen agama RI, 2003.

James A, O'Brein, Pengantar Sistem Informasi. Jakarta: Salemba, 2005.

Jogiyanto, HM, Analisis Dan Desain Sistem Informasi Pendekatan Terstruktur Teori Dan Praktek Aplikasi Bisnis. Yogyakarta: Andi, 2005.

Kadir, Abdul, Pengelolaan Sistem Informasi. Yogyakarta: Andi, 2003.

Kumorotomo, Wahyudi dan Subando Agus Margono, Sistem Informasi Manajemen. Yogyakarta:Gajah Mada University Press, 2004.

Kantor Wilayah Kementrian Agama, Buku Panduan Aplikasi Sistem Informasi Manajemen Nikah (SIMKAH), (tth).

Keputusan Direktur Jendral Bimbingan Masyarakat Islam Nomor DJ.II/369, Penerapan Sisistem Informasi Manajemen Nikah (SIMKAH) pada Kantor Urusan Agama (KUA) Kecamatan. Tahun 2013.

Marzuki, M. Ervan dan Hasbi Mustofa, Efektivitas Pelayanan Di Seksi Bimbingan Masyarakat Islam Kantor Kementerian Agama, (jurnal)., tth

Molleong, Lexy J. Metode Penelititan Kualitatif. Bandung: Remaja Rosda Karya, 1999.

Mulyanto, Agus, Sistem Informasi Konsep dan Aplikasi, (Yogyakarta:Pustaka Pelajar, 2009.

Moenir, H.A.S. 2002. Manajemen Pelayanan Umum di Indonesia. Jakarta : Bumi Aksara, 2002.

Mayangsari, Rr. Rizadian \& Eva Hany Fanida, Efektivitas Penerapan Sistem Informasi Manajemen Nikah

e-ISSN: 2715-4580 p-ISSN: 2715-8268 
(SIMKAH) di Kantor Urusan Agama. Ilmu Administrasi Negara, Fish, UNESA,2013.

Marzuki, M. Ervan dan Hasbi Mustofa, Efektivitas Pelayanan di Seksi Bimbingan Masyarakat Islam Kantor Kementerian Agama, (tth).

Nuruddin, Amiur dan Azhari Akmal Tarigan, Hukum Perdata Islam di Indonesia: Studi Kritis Perkmbangan Hukum Islam dari Fikih. Cet. Ke 3; Jakarta: Pranada Media Group, 2004.

Nasution, Khairuddin, Hukum Perdata (keluarga) Islam Indonesia dan Perbandingan Hukum Perkawinan di Dunia Muslim. Yogyakarta: Academia \& Tazzafa, 2009.

Nurdin. (2014, 28-30 May 2014). Understanding government eprocurement effectiveness from users' perspectives: A case of social media discussion in Indonesia local government. Information and Communication Technology (ICoICT), 2014

Nurdin, N. (2016). The Roles of Information Technology in Islamic Bank Knowledge Management: A study of Two Syariah Banks in Palu. Hunafa: Jurnal Studia Islamika, 13(2), 181-217. https://doi.org/https://doi.org/1 0.24239/jsi.v13i2.444.181-217

Nurdin, N. (2017a). Research in Online Space: The Use of Social Media for Research Setting Jurnal Sistem Informasi (Journal of Information System), 13(1), 67-77.

Nurdin, N. (2017b). To Research Online or Not to Research Online: Using Internet-Based Research in Islamic
Studies Context. Indonesian Journal of Islam and Muslim Societies, 7(1), 31-54.

P. Siangan, Sondang, Fungsi- fungsi Manajerial. Jakarta: PT. Bumi Aksara, 2002.

Ratminto dan Atik Septi Winarsih, Manajemen Pelayanan. Yogyakarta:Pustaka Pelajar, 2006.

Rofiq, Ahmad, Psikologi Islami. Bandung. PT. Rosdakarya, 2002.

Rusli, R. (2017). Wahdah Islamiyyah Palu: on Contemporary Islamic Legal Issues in The Internet. Hunafa: Jurnal Studia Islamika, 14(2).

Rusli, R. (2017). Wahdah Islamiyyah Palu: on Contemporary Islamic Legal Issues in The Internet. Hunafa: Jurnal Studia Islamika, 14(2).

Satriani, Ade Ani, "Penerapan Sistem Informasi Manajemen Nikah (SIMKAH) online di KUA Kota Surabaya Dalam Perspektif PMA No 11 Tahun 2007". Surabaya:prodi Al- Ahwal Al- Syakhshiyyah, Jurusan Hukum Islam, Fakultas Syariah dan Hukum, UIN Sunan Ampel, 2014.

Safwat, Ahmad, Qa'idat Ijlah Qanun alIh\{wal al-Shakhsiyah, makalah pada pertemuan bar Association di Alexandria. Mesir, tanggal 5 Oktober 1917.

Surkalam, Luthfi, Kawin Kontrak dalam Hukum Nasional Kita. Pamulang: CV Pamulang, 2005.

Soeroso, R., Ilmu Hukum. Jakarta: Sinar Grafika, 1993. 
Soemiyati. Hukum Perkawinan Islam dan

Undang-Undang Perkawinan.

Yogyakarta: Liberti, 1982.

Setiawan, Aries, SIMKAH panduan

SIMKAH, 2. Jakarta, 2010.

Sorina Irna, Rancang Bangun System Informasi, Sistem informasi pencatatan buku nikah, KUA Gerunggang. Pangkalpinang: Sistem Informasi STMIK ATMA LUHUR, 2016.

Setiawan, Aries, SIMKAH. Panduan Simkah, 2010.

Susanti, Dyah Ochtorina dan A'an Efendi, Penelitian Hukum (Legal Research), . Jakarta: Sinar Grafika, 2014.

Sukandarrumidi, Metodologi Penelitian. Yogyakarta: Gajah Mada University Press, 2004.

Saefullah, Konsep dan Metode Pelayanan Umum yang Baik, dalam Jurnal Ilmu Sosial dan Ilmu Politik. Sumedang: FISIP UNPAD, 1999.

Tim Reality, Kamus Terbaru Bahasa Indonesia Dilengkapi: EYD;Ejaan Yang Disempurnakan. Cet.I., Reality Publisher: Surabaya, 2008.

Thalib, Sayuthi, Hukum Kekeluargaan Indonesia. Jakarta: UI Press, 1986.

Tihami, M.A \& Sohari Sahrani, Fikih Munakahat. Jakarta: Raja Pera, 2009.

fikih Munakahat Kajian Nikah Lengkap. Jakarta: PT.Raja Grafindo Persada,2009.

Yayan Sopyan, Islam Negara Transformasi Hukum Perkawinan Islam dalam Hukum Nasional, th.

Zahrah, Abu, al-Ih\{wal al-Shakhsiyah. Mesir: Dar al-Fikr al-'Arabi, 1957. 